\title{
Damage characteristics and distribution patterns of invasive pest, Spodoptera frugiperda (J.E Smith) (Lepidoptera: Noctuidae) on maize crop in Bali, Indonesia
}

\author{
I WAYAN SUPARTHA ${ }^{1, \boldsymbol{v}}$, I WAYAN SUSILA ${ }^{1}$, ANAK AGUNG AYU AGUNG SRI SUNARI ${ }^{1}$, \\ I. G. FEBRI MAHAPUTRA ${ }^{2}$, I KADEK WISMA YUDHA ${ }^{2}$, PUTU ANGGA WIRADANA ${ }^{3}$ \\ ${ }^{1}$ Laboratory of Integrated Pest Management, Faculty of Agriculture, Universitas Udayana. Jl. P.B. Sudirman, Denpasar 80234, Bali, Indonesia. \\ Tel. +62 822-4796-6490, Fax.: +62-361-701907, ”email: yansupartha@ yahoo.com \\ ${ }^{2}$ Dry Land Agriculture Graduate Program, Faculty of Agriculture, Universitas Udayana. Jl. P.B. Sudirman, Denpasar 80234, Bali, Indonesia \\ ${ }^{3}$ Program of Biology, Faculty of Health, Science and Technology, Universitas Dhyana Pura. Jl. Raya Padang Luwih, North Kuta, Badung 80361, Bali, \\ Indonesia
}

Manuscript received: 12 April 2021. Revision accepted: 26 May 2021

\begin{abstract}
Supartha IW, Susila IW, Sunari AAAAS, Mahaputra IGF, Yudha IKW, Wiradana PA. 2021. Damage characteristics and distribution patterns of invasive pest, Spodoptera frugiperda (J.E Smith) (Lepidoptera: Noctuidae) on maize crop in Bali, Indonesia. Biodiversitas 22: 3378-3387. The Fall Armyworm (FAW), Spodoptera frugiperda (Lepidoptera: Noctuidae) is a destructive crop pest native to North and South America which has now been reported to have spread to Indonesia. This study aims to ensure the attack and spread of invasive pests FAW on corn crops in Bali Province, Indonesia. In addition, it also studied population structure, age structure, and percentage of attacks on maize crops in high altitude areas in Bali. The research was conducted using survey methods. A sampling of plants is carried out in all districts and cities in the Bali by diagonal sampling. The sample unit size is $5 \mathrm{~m} \times 5 \mathrm{~m}$ with the number of plants observed being 150 plants. The score of plant damage at the age of 4 weeks after planting (WAP) plants has a "very heavy" attack intensity value. Areas of upper leaves or young leaves most affected by $S$. frugiperda attack in the field. The results showed that pest FAW has been entering and attacking maize crops in Bali since January 2020 as the first report. At the beginning of the entry was only found in some lowland locations, especially in Tabanan and Jembrana regency, but within the next 4 months, it has spread evenly in all districts and cities in Bali. Adults populations and egg groups of FAW were found to peak by the time the corn crop was 2 weeks old after planting while the larval population reached its peak by the time the plant was 4 WAP The highest percentage of FAW attacks is in altitude areas below 250 meters above sea level (masl) with an average attack per observation plot of $47.84 \%$. This research is the first to report on FAW attacks on maize crops in Bali since January 2020 and adds to our knowledge of FAW pests on maize crops in Bali.
\end{abstract}

Keywords: Bali, fall armyworm, maize commodities, invasive pest, Spodoptera frugiperda

\section{INTRODUCTION}

Apart from wheat and rice, maize or corn (Zea mays L.) is a source of food plant that provides carbohydrates (Shah et al. 2016). The maize plant originated in Central America and has since spread to tropical regions all over the world (Edmeades et al. 2017). The provinces of East Java, Central Java, Lampung, South Sulawesi, West Java, North Sumatra, Gorontalo, North Sulawesi, West Sumatra, and East Nusa Tenggara currently have maize production centers in Indonesia (Anon 2019). Maize production has fluctuated from 2011 to 2015 , namely 17,643 tons in succession in $2011 ; 19,387$ tons in 2012 ; 18,511 tons in $2013 ; 19,008$ tons in 2014; 19,287 tonnes and 19,612 tonnes in 2015 (Anon 2019a). The invasion of plant pests is one factor causing fluctuations in maize production in Indonesia (Anon 2019b).

Pests, viruses, and weeds are the three categories of plant pests (Ratnadass et al. 2012). Pests such as shoot fly (Atherigona spp.), soil worms (Agrotis sp.), spotted stem borer (Chilo partellus), pink stem borer (Sesamia inferens), and fall armyworms (Spodoptera frugiperda.) (Anon 2021). However, recently, a new invasive pest has entered
Indonesia, namely Spodoptera frugiperda or the Fall Armyworm (FAW) (Nelly et al. 2021; Supartha et al. 2021).

The Fall Armyworm (FAW) Spodoptera frugiperda J. E. Smith (Lepidoptera: Noctuidae) is a polyphagous pest that attacks more than 353 plant species from 76 different families, including Poaceae, Fabaceae, Solanaceae, Asteraceae, Rosaceae, and Brassicaceae (Montezano et al. 2018; Kansiime et al. 2019). FAW can damage corn crops through leaf borer larvae. Instar-1 larvae initially feed on leaf tissues and leave a transparent layer of the epidermis. However, then the larvae will make a hole in the leaves that are still rolling. Late instar larvae can cause severe damage that often leaves only the bones of the leaves and stems of corn crops (Reddy 2019). The $S$. frugiperda can attack corn crop from the vegetative to generative phase, but in the vegetative phase, the level of damage by $S$. frugiperda attacks is higher than the generative phase (Prasanna et al. 2018). Damage to corncobs and leaves resulted in significant yield losses as happened in Honduras resulting in a yield loss of up to $40 \%$, in Argentina by $72 \%$, and in Africa ranging from 21-53\% (Rwomushana et al. 2018). 
In other countries, the spread of FAW began from attacking maize crops in the tropics of the United States to Argentina (Sparks 1979). In 2016 for the first time, the pest reportedly invaded maize crops in West and Central Africa (Benin, Nigeria, Sao Tome, Principe, and Tongo) (Goergen et al. 2016) and then spread throughout the African continent (Prasanna et al. 2018). In 2018, FAW pests were already in India and reportedly first attacked maize crops in Karnataka (Ganiger et al. 2018). FAW pests are predicted to have spread more widely throughout the world. The FAW's potential spread can be aided by wind acting as a major contaminant of traded commodities, and as a stowaway on or off an aircraft (Goergen et al. 2016). In early 2019, FAW pests were found in maize crops in Indonesia, namely Sumatra, and in July 2019 have reportedly attacked maize crops in West Java areas such as Bandung, Garut, and Sumedang (Anon 2019).

Until now, research on attack characteristics, population structure, and distribution of S. frugiperda in Bali Province, Indonesia is still limited. Based on this phenomenon, it is necessary to carry out further research to understand the characteristics of the $S$. frugiperda attack as an initial effort to understand its attacks on maize in the field. Research on the population structure and distribution of $S$. frugiperda pests will provide an overview of the damage that these pests will cause. Based on this information, this study aims to understand the characteristics of damage caused by $S$. frugiperda on maize in Bali, analyze the distribution, population structure, and attack of FAW, S. frugiperda in maize cropping in Bali, Indonesia. The results of our research are expected to provide information that local farmers and the government can use to formulate policies in controlling the $S$. frugiperda pest in Bali.

\section{MATERIALS AND METHODS}

\section{Study area}

Sampling was conducted in all regencies and cities in Bali, Indonesia (See Figure 1). Laboratory research was conducted in the Integrated Pest and Disease Management Laboratory of the Faculty of Agriculture, Udayana University, Denpasar. The research was conducted from January to July 2020.

\section{Sampling}

Purposive sampling was used to determine research locations in each district. Sampling on maize was carried out by diagonal sampling with a sample unit size of $5 \mathrm{~m} \times$ $5 \mathrm{~m}$. The number of plants observed in each sample unit was 150 plants. The sample plants were observed directly in the field against attack symptoms, attack intensity, and the population of $S$. frugiperda (Figure 2).

\section{Damage characteristics}

Observation of the characteristics of damage caused by pest attacks can be determined by observing (i) attack behavior and symptoms, (ii) attack intensity, and (iii) the number of affected leaves per plant.

Observation of larvae behavior and attack symptoms were observed in the infected maize plant by observing directly, the attack behavior was when the eggs were laid, where they were placed, and how the larvae behaved after hatching until before they become pupae. The attack behavior observed was how the larvae attacked and the plant parts that were attacked. Symptoms of the attack were observed on the leaves of maize plants which were observed were symptoms of the damage and the form of the damage.

Observation of attack intensity is carried out by assessing any damage to plants attacked by $S$. frugiperda on a scale of 1-9 (Davis and Williams 1992):

$$
\mathrm{I}=\frac{\Sigma(n \times v)}{N \times Z} \times 100 \%
$$

Where:

$I \quad=$ attack intensity

$Z \quad=$ Highest score (score) (9)

$N \quad$ = number of plants observed

$n \quad=$ number of plants that have a " $\mathrm{v}$ " value (crop damage)

$v \quad=$ the value (score) of crop damage based on the criteria in Figure 3.

The determination of the attack category was based on leaf damage and was divided into three age groups (weeks after planting) (Table 1).

Observation of the number of infected maize leaves per plant was by observing as many as 300 plants attacked by $S$. frugiperda larvae randomly in the field. The plants observed were maize plants that were 6 weeks old after planting (WAP) because almost all of the leaves had come out and were about to enter the generative phase, which was calculated as the number of infected leaves and the total number of maize leaves.

\section{Distribution of $S$. frugiperda}

The spatial pattern of the FAW population was measured using a formula from Jim et al. (1998) :

$$
\begin{aligned}
& \mathbf{S}^{\mathbf{2}}=\frac{\mathbf{\Sigma}(\mathbf{X i}-\mathbf{X})}{\boldsymbol{n}-\mathbf{1}} \\
& \text { Where: } \\
& S^{2}=\text { variance } \\
& X i=10^{\text {th }} \mathrm{X} \\
& X=\mathrm{X} \text { average } \\
& n=\text { total sampling } \\
& \text { Criteria: } \\
& \mathrm{S}^{2} / \mathrm{X}<1 \text { : regular distribution pattern } \\
& \mathrm{S}^{2} / \mathrm{X}=1: \text { random spread pattern } \\
& \mathrm{S}^{2} / \mathrm{X}>1: \text { group distribution pattern }
\end{aligned}
$$

The measurement of distribution at each point of sampling pests is displayed in the population distribution map in Bali, Indonesia. 


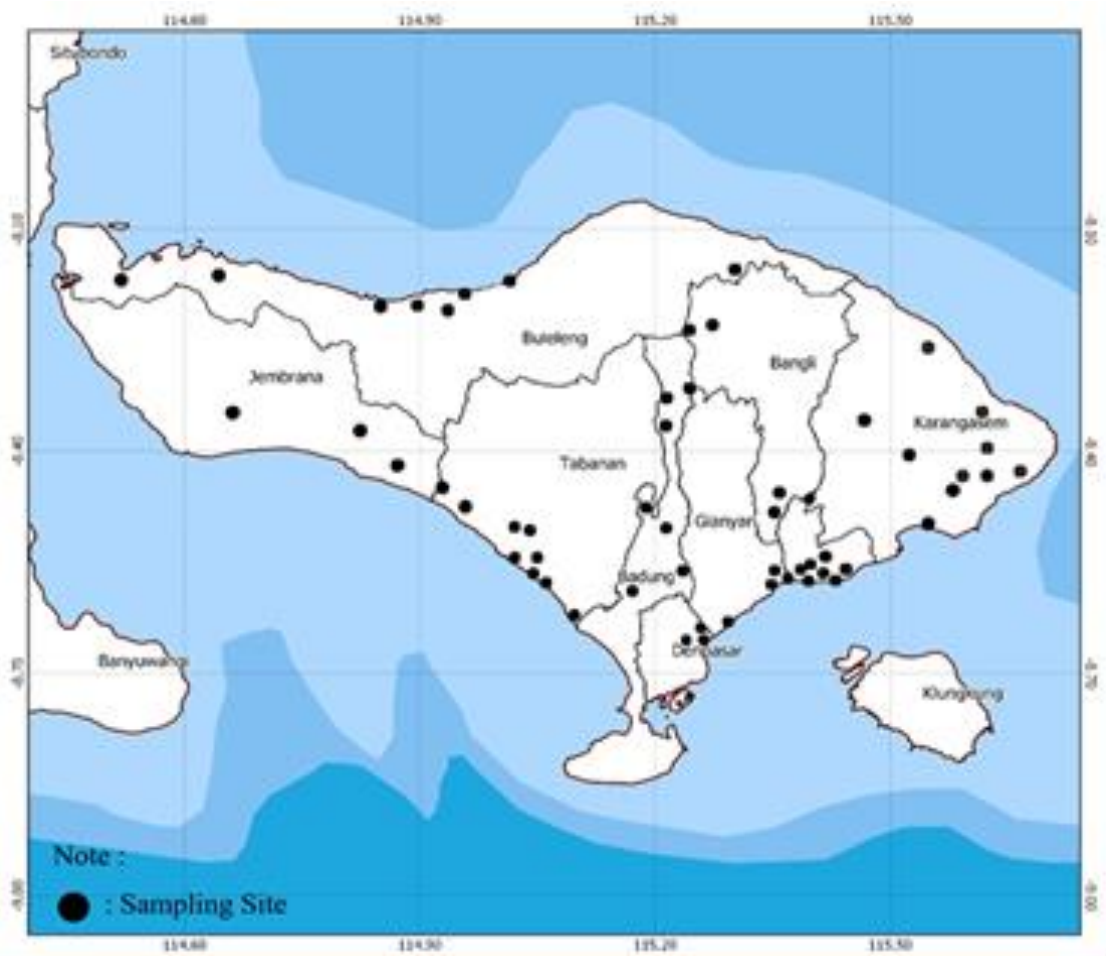

Figure 1. Sampling site of this study Bali Province, Indonesia

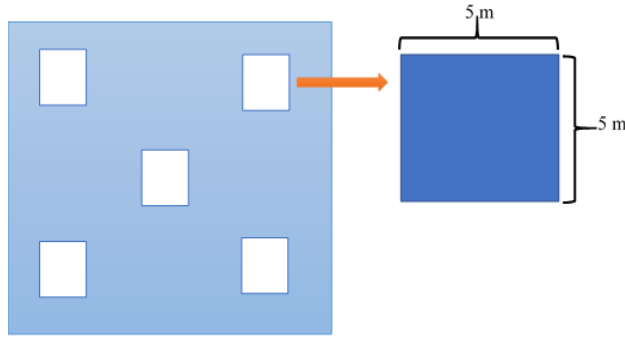

Figure 2. Sampling method in field
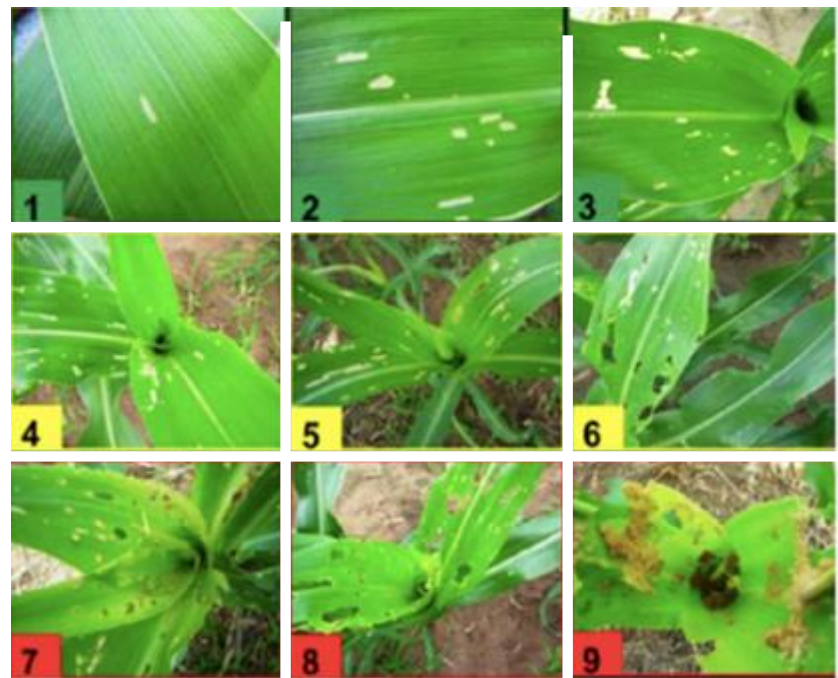

Figure 3. Davis scale value (Davis and Will ams 1992)

Table 1. Criteria for S. frugiperda attack

\begin{tabular}{lccc}
\hline \multirow{2}{*}{ Criteria } & \multicolumn{3}{c}{ Weeks after planting (WAP) } \\
\cline { 2 - 4 } \multicolumn{1}{c}{$\mathbf{0 - 2}$} & $\mathbf{2 - 4}$ & $\mathbf{> 4}$ \\
\hline Slight & $0-10$ & $0-20$ & $0-40$ \\
Moderate & $10-20$ & $20-40$ & $40-60$ \\
Heaviness & $20-40$ & $40-60$ & $60-75$ \\
Very heavy & $40-85$ & $60-85$ & $75-85$ \\
No result & $>85$ & $>85$ & $>85$ \\
Economic threshold & $15 \%$ & $30 \%$ & $50 \%$ \\
\hline
\end{tabular}

Population and age structure of $S$. frugiperda

Observation of population structure is carried out by calculating the number of adults, the number of egg groups and the lifespan of instar larvae 1-6 found on the observation plot directly in the field. Meanwhile, FAW pest age structure observations in districts and cities in Bali, Indonesia were conducted by an average number of adults, egg group, and larva instar 1-6 in sample units found in each district and city in Bali.

\section{Attack percentage (\%)}

Observation of FAW pest attack percentage is done by calculating the number of plants affected at each height of 0-250 meters above sea level, >250-500 meters above sea level, and >500 meters above sea level and then analyzed using a formula (Putrasamedja et al. 2016):

$$
\boldsymbol{P}=\frac{a}{b} \boldsymbol{x} 100 \%
$$

Where :

$P:$ percentage of infected plants

$\alpha:$ number of affected plants

$b:$ number of plants observed

\section{Data analysis}

The level of attack, population structure, spatial distribution pattern, attack percentage, and the age structure of $S$. frugiperda pests in regencies/cities in Bali was calculated using software Ms. Excel 2019 (Microsoft, USA) and the data obtained are displayed in the form of tables and figures, while the behavior and symptoms of $S$. frugiperda were analyzed using descriptive analysis methods. 


\section{RESULTS AND DISCUSSION}

\section{Behavior and symptoms of $S$. frugiperda larvae damage to maize}

Spodoptera frugiperda risk behavior and symptoms are critical indicators for determining the prevalence of these pests in maize crop fields, particularly because such pests are new to Indonesia. Grinding indications, such as hollow leaves and larval droppings, show damage to maize plants caused by $S$. frugiperda larvae attack.

Attack behavior is one of the most important indicators for identifying pests in a crop, and it could be used to differentiate between various types of pests. Symptoms of $S$. frugiperda attack and damage to maize crops include the appearance of grinding marks on the leaves in the type of gaps, damaged leaves, and the presence of larval droppings. The observations indicated that before the damage symptoms were preceded by the presence of female moth $S$. frugiperda in the field and laying eggs on the top or bottom surface of the young corn leaves on leaves 2-4 from above. Eggs are laid in groups, with the number reaching 150-200 eggs per group of eggs covered with brownish fine hairs (Tendeng et al. 2019). The larvae hatch after 3-5 days, and after hatching the larvae are immediately active in eating the leaves of the corn plant (CABI and FAO 2019).

The newly hatched instar-1 larvae feed on the lower surface of the leaves in groups and leave the upper epidermal layer that appears transparent. Research reports that these larvae can also eat parts of the leaf chlorophyll which can cause the transparent layer to appear silver in color and eventually the ingested leaves produce white patches that extend on plant leaves (Dhar et al. 2019).

The results of observations in the field showed that $S$. frugiperda females laid eggs on the top or bottom surface of young maize leaves 1 week after planting (wap). One group of eggs is 50-200 eggs. The eggs are laid in groups that are covered by soft brownish hairs. Larvae hatch after 3-5 days. After hatching, the larvae are immediately active in eating the leaves of the corn plant. The newly hatched instar-1 larvae actively feed in groups on the undersides of young leaves and leave a transparent epidermal layer (Figure 4.D).

Instar larvae 2 and 3 (Figure 5.A and 5.B) boreholes in the shoots and growth points of the maize plant. The larvae feed on the leaves from the edge to the inside so that the leaves are hollow and cut off after opening. The holes in the leaf are like parallel panes (Figure 5.C). The larvae hide in their burrows and actively eat there. The larvae actively feed at night. Above the winch is covered with dirt (Figure 5.D). The feces of the new S. frugiperda larvae are brown to dark brown, while the dung of the dried S. frugiperda larvae is light brown and resembles sawdust (rather coarse). Feces from $S$. frugiperda larvae were found on the top surface of the leaves and around the shoots of the plant (Figure 5.D). Instar-2 and 3 larvae boreholes at the plant's developing stage and consume the leaves from the outside in, causing the leaves to become hollow and damaged after completely opening. The hole in the leaf resembles a parallel window glass, except the tip of the leaf has been severed. Larvae usually hide in burrows and regularly feed on there. Furthermore, larvae actively feed at night (Deole and Paul 2018). The larval feces of the newly released $S$. frugiperda larvae have a brown to dark brown color, while the dried feces of the $S$. frugiperda larvae are light brown, resembling sawdust (rather coarse). The feces of $S$. frugiperda larvae are found on the top surface of the leaves, or around the shoots of corn plants (Anon, 2019).

The 4-6 instar larvae (Figure 6.A-C) can cause serious damage to the corn plant's bones and stems. These larvae cut the maize plant's increasing stage in heavy attacks, causing the plant to fail. The larvae move to another plant until the crop has been severely damaged (Figure 6.D). According to our findings, 4-6 instar larvae can cause significant damage to maize crops. In heavy infestations, the larvae will cut off the growth points and often leave only the leaf bones and stalks of the maize plant, resulting in the plant's death. For an average population density of 0.2-0.8 larvae per plant, yield productivity can be reduced by $5-20 \%$. Larvae will normally migrate to other healthy plants if the plant has been severely infected (Anon 2019).

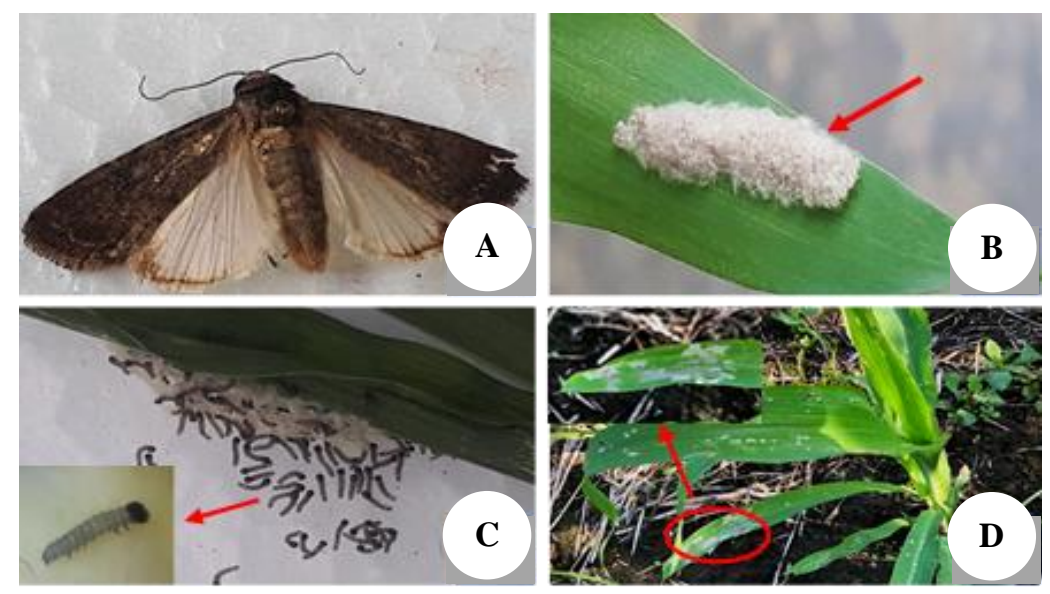

Figure 4. Adult female, S. frugiperda (A), egg group (B), Larva instar-1 (C), Symptoms of attack of Larva Instar-1 (D) 

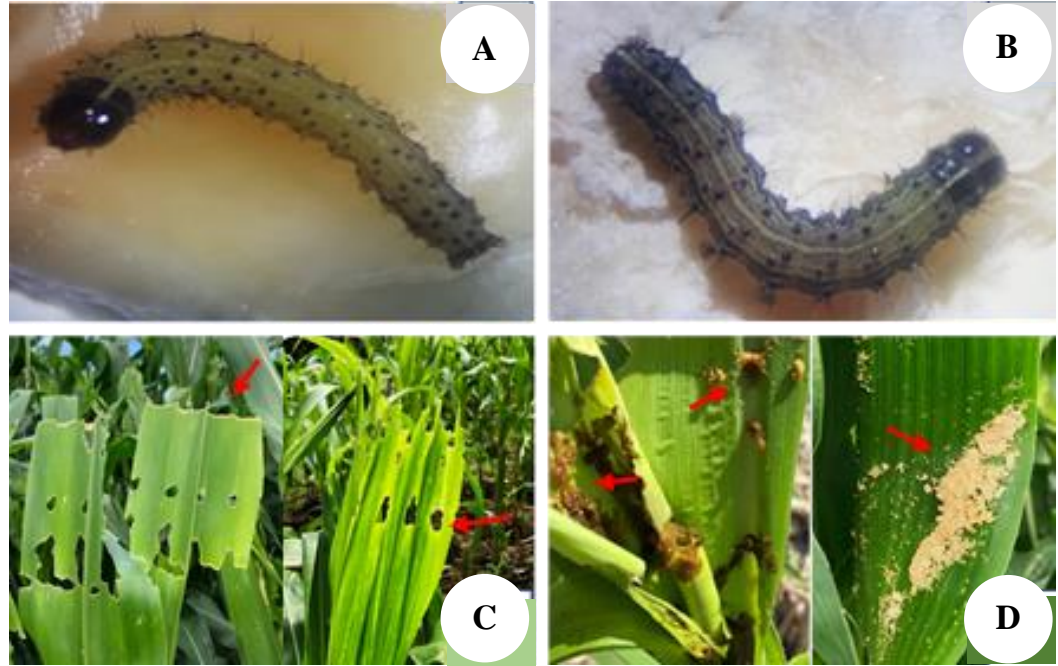

Figure 5. Larvae of $S$. frugiperda instar-2 (A), Larva of $S$. frugiperda $3^{\text {rd }}$ instar (B), Typical symptoms of larvae attack leaves (C), Larvae feces (D)
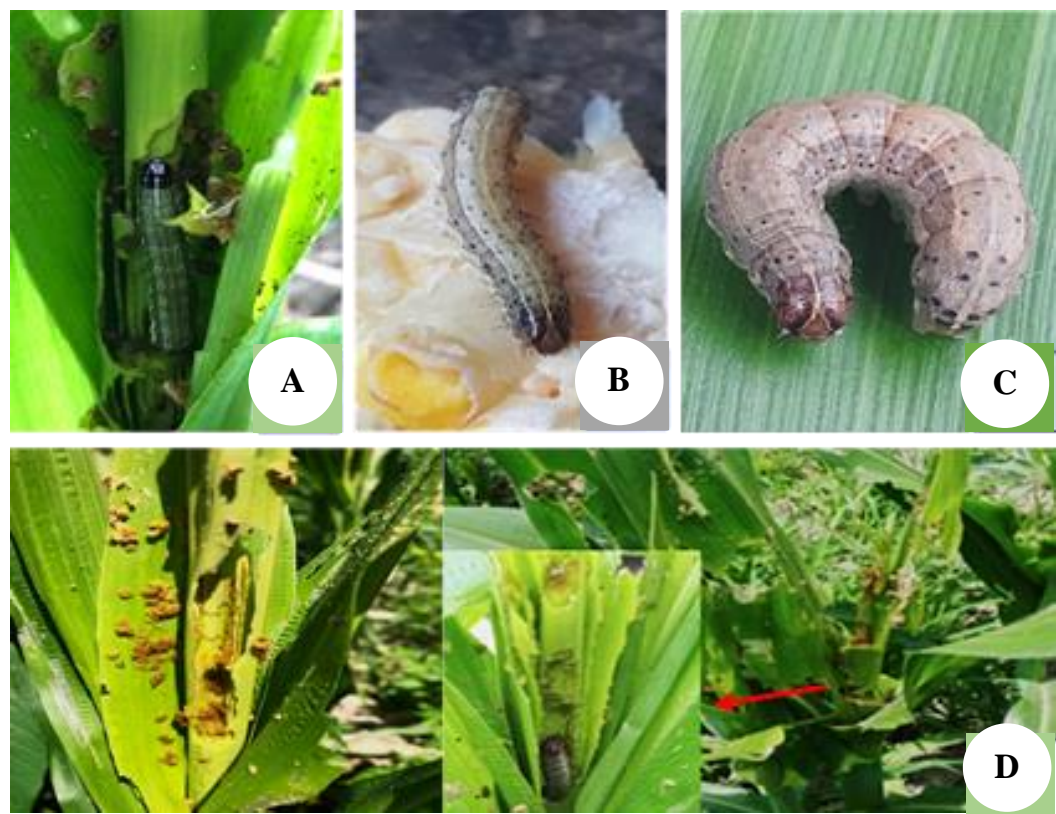

Figure 6. Larvae $S$. frugiperda instar-4 (A), Larva S. frugiperda Instar-5 (B), Larvae S. frugiperda instar-6 (C), Symptoms of severe damage (D)

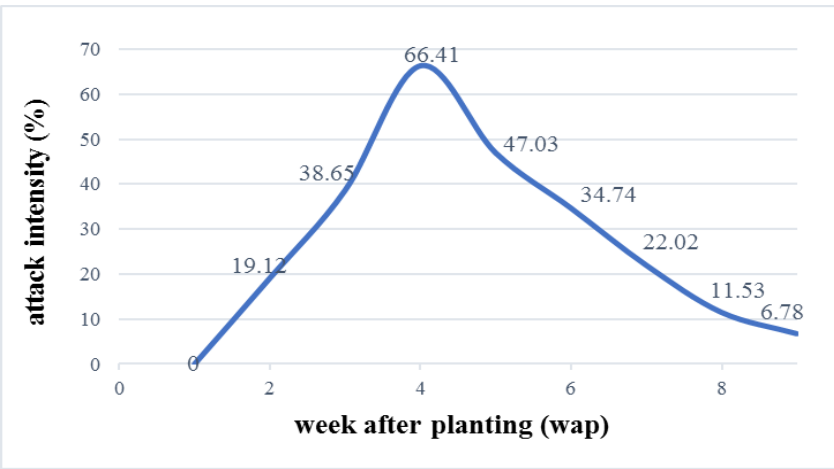

Figure 7. The intensity of $S$. frugiperda attacks on maize in Bali

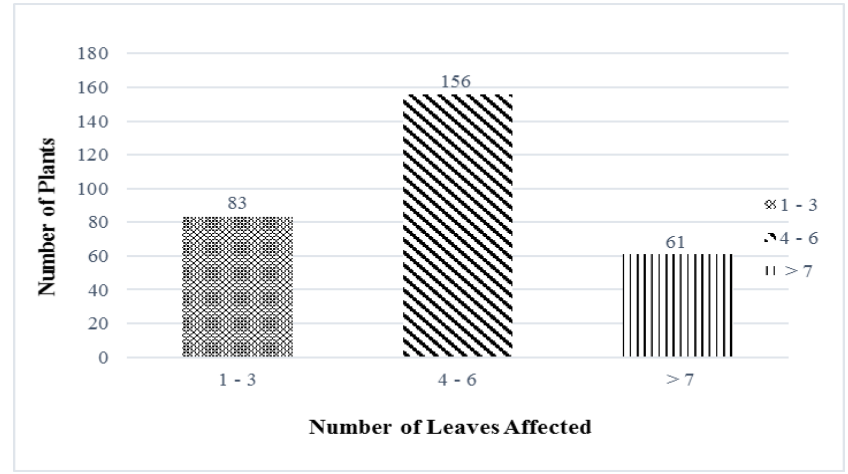

Figure 8. The range of the number of leaves attacked by $S$. frugiperda per plant 


\section{The intensity of $S$. frugiperda attack on maize in Bali}

Our observations show that the intensity of $S$. frugiperda attacks on maize in Bali varies widely, ranging from $6.78 \%-66.41 \%$ (Figure 7).

The results of the analysis showed that $S$. frugiperda attack on maize was started at the $2^{\text {nd }}$ week after planting (WAP) with "moderate" attack intensity (19.12\%)/plant. The attack intensity continued to increase until its peak at the $4^{\text {th }}$ WAP with "very heavy" attack intensity $(66.41 \%) /$ plant. The attack intensity decreased at week $5^{\text {th }}$ with "moderate" attack intensity (47.03\%) / plant and continued to decrease until it reached the lowest value at the $9^{\text {th }}$ wap with a "mild" attack intensity $(6.78 \%) /$ plant. Based on the table of the score of plant damage at the age of 4 wap plants, it has a "very heavy" attack intensity value, and these results indicate that $S$. frugiperda larvae have high destructive power and have the potential to reduce the productivity of maize in the field.

According to research from Chimweta et al. (2020), damage and loss of crop yields caused by armyworms can be influenced by the stage and level of vulnerability of plants in addition to population density and insect pest stadia. The higher the pest population density, the heavier the damage it causes. The severity of crop damage is also influenced by the destructive ability of a pest (Pathania et al. 2020). The ability to damage $S$. frugiperda larvae is 10 times heavier when compared to other corn leaf-eating pests (CABI and FAO 2019). Plant damage caused by $S$. frugiperda is more severe in the vegetative phase (Suby et al. 2020).

\section{The range of the number of maize leaves attacked by $S$.} frugiperda larvae per plant

The study indicates that $S$. frugiperda attacks on maize plant leaves occurred at the shoots or increasing points of maize plants, and the number of infected leaves per plant ranged from 1-9 leaves (Figure 8). The most infected leaves per plant were 4-6 leaves (156 plants), followed by 1-3 leaves ( 83 plants), and the least affected per plant were 7-9 leaves (61 plants). The leaves targeted by $S$. frugiperda may be at the top, middle, or very bottom of the corn plant, but in the leaf area, the top or young leaves were the most affected.

Our results indicated that $S$. frugiperda preferred the young leaves or the top blades of maize among the affected leaves. This is similar to Dhar et al. (2019) that $S$. frugiperda larvae prefer to eat younger maize leaves. We assumed that older corn leaves tended to have thicker and stiffer cell walls and thus less favored by leaf-eating insects. Meanwhile, young plant leaves have much softer tissue-making cells so that insect larvae prefer them (Badenes-Perez et al. 2014; Bhusal and Bhattarai 2019). In addition, young leaves usually contain more water (succulent), so it is very popular with phytophage insects (Supartha et al. 2020).

\section{Distribution of $S$. frugiperda in Bali}

FAW's attack on maize crops in Bali has first discovered in Jembrana and Tabanan regency on January 07, 2020. Similar observations were made during the week on maize crops in other districts, there have been no symptoms of attacks on corn crops. Further observations made in February 2020 began to be found in districts other than Jembrana and Tabanan. FAW attacks were found in Badung, Denpasar, Buleleng, and Klungkung districts. While similar attacks in Gianyar and Bangli districts were only discovered in the observation period in March and April 2020. The last attack of FAW was found in Karangasem Regency, the eastern tip of Bali Island, precisely in Sengkidu Village during the observation period in May 2020. The process of pest invasion of FAW on all corn crops in Bali occurred within four months, starting from January-May 2020 (Figure 9).

FAW pests are species that have very strong adaptability and distribution because their adult roaming ability is very high. Adult FAW can fly for $100 \mathrm{~km}$ for 1-3 consecutive nights with a duration of 10 hours per night (Fan et al. 2020). The ability is supported by its small body size and assisted also by the wind. The results showed that FAW that spread evenly throughout districts/cities in Bali has a random distribution pattern $\left(S^{2} / X=1\right)$. The pattern of spread is caused by the urge to find food, avoid predators, influence the climate, and get carried away by the wind (Supartha et al. 2020).

During the study, FAW pests were found only on maize crops. Currently, there are still no strong indications about the preference of host crops other than corn crops for this pest. The development of larvae depends on the preference of adults to the host plant chosen or preferred because it is closely related to the nutritional content of the host plant that corresponds to the growth and development needs of such insects (Barros et al. 2010). Some gramineous crops such as corn, wheat and sorghum are considered host plants that are particularly suitable for FAW (Wu et al. 2019; Ba et al. 2020).

\section{Population structure of $S$. frugiperda}

Adult FAW begins to come and lay eggs since the corn crop is 1 week old after planting (WAP), which is characterized by the presence of adult and egg groups on the leaves of plants (Figure 10). The source of the invasion of moths is thought to be strong from the maize map that is around the cropping site because the expanse applies a pattern of planting corn that is not in unison in the growing season. The presence of moths to the corn crop is stimulated and guided by chemical compounds secreted by young corn crops. The corn plants can secrete chemical compounds in the form of phenol compounds, one of which is vanillic acid as a stimulant compound for adult moths to lay eggs (Santiago et al. 2005; Horvat et al. 2020). FAW egg group has been around since the plant is 1 WAP and reaches its peak by the time the plant is 2 WAP. The group of eggs hatched into larvae of instar 1 by the time the eggs were between 2-3 days old (CABI 2017).

The results showed that instar larvae 1 and 2 were already found by the time the corn crop was 2 WAP and reached the peak of the population at the age of 3 WAP with an average number of 34.97 and 28.78 larvae per plot. The population of instar-3 larvae reaches its peak in corn crops aged 4 WAP which is 27.87 larvae per plot, while the 
population of instar larvae 4 and 5 reaches its peak at the plant age of 5 wap of 19.18 and 15.78 heads per plot. The population of instar-6 larvae reaches its peak at the plant age of 6 WAP which is 13.87 larvae per plot. Once it reaches its peak, instar 1-6 larvae will experience a weekly decline caused by changes in the instar larvae at each instar level.

The decrease in the larval population can also be due to the presence of various obstacles in developing insects. Some of these barrier factors are extrinsic and intrinsic factors. The obstacle to the eccentric factor is the reduced number and quality of food sources used to meet their needs and other environmental factors that do not support their development (Montezano et al. 2018; Anandhi et al. 2020). Yasa et al. (2020) also asserted that the adequacy of food, climate, competitors, and natural enemies are environmental factors that greatly influence the growth and development of populations that eventually affect the decline of insect pest populations. Other environmental factors that affect the growth, development, and density of insect pest populations are the living space and accessibility of resources and the ability of these individuals to reach and obtain the necessary resources including the nature of the spread, scattering, and ability to find these resources (Supartha et al. 2021).
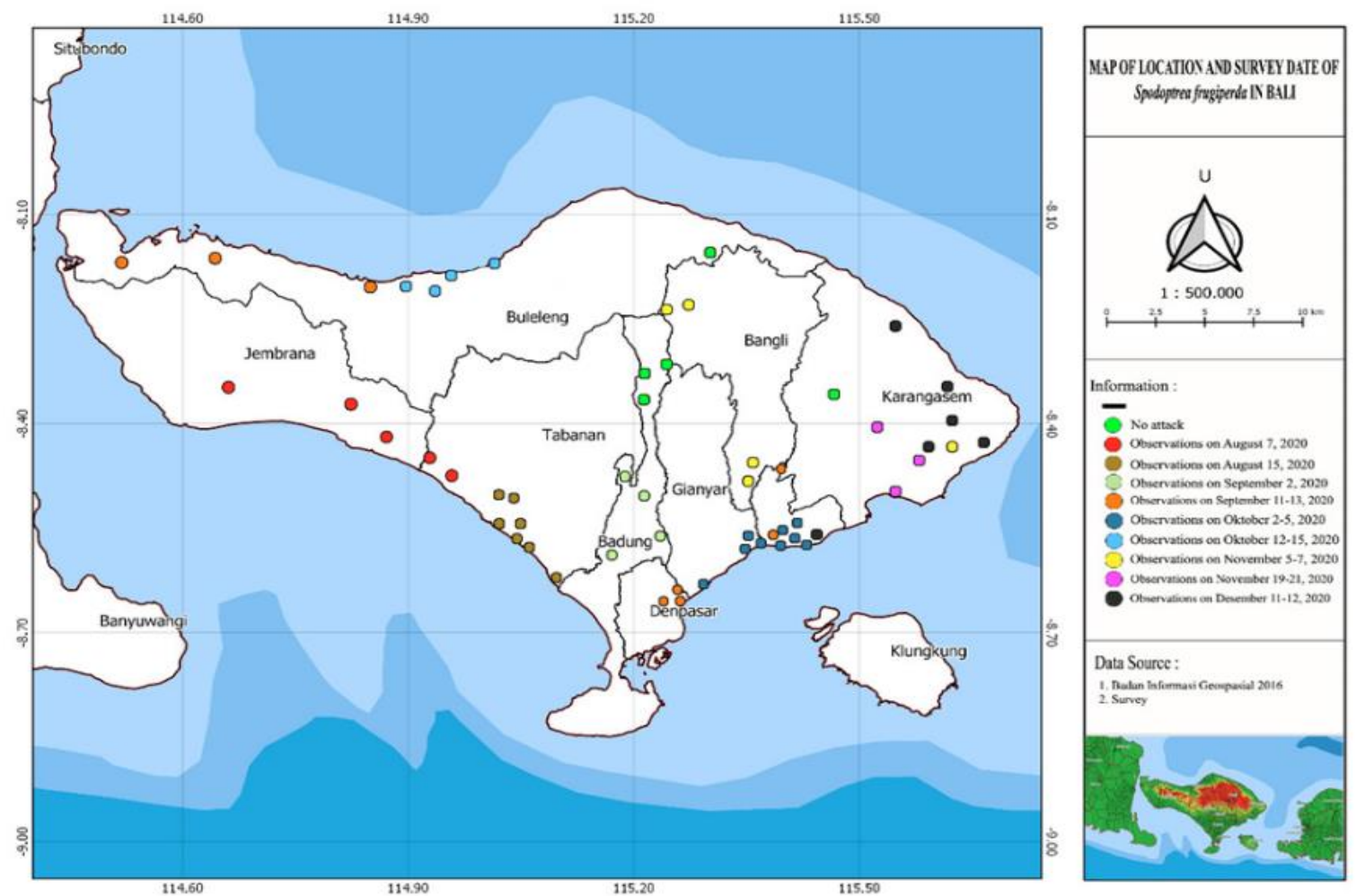

Figure 9. Distribution map of FAW, S. frugiperda in Bali

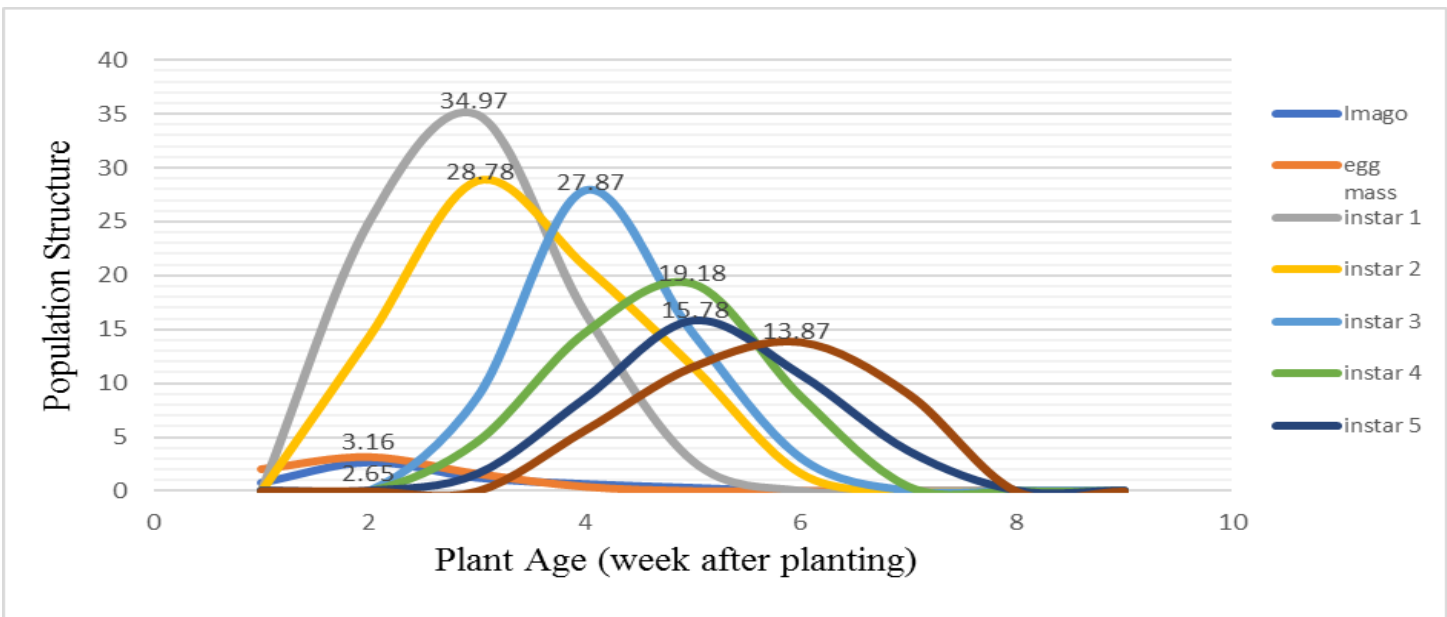

Figure 10. Population structure of $S$. frugiperda on maize crops in Bali 


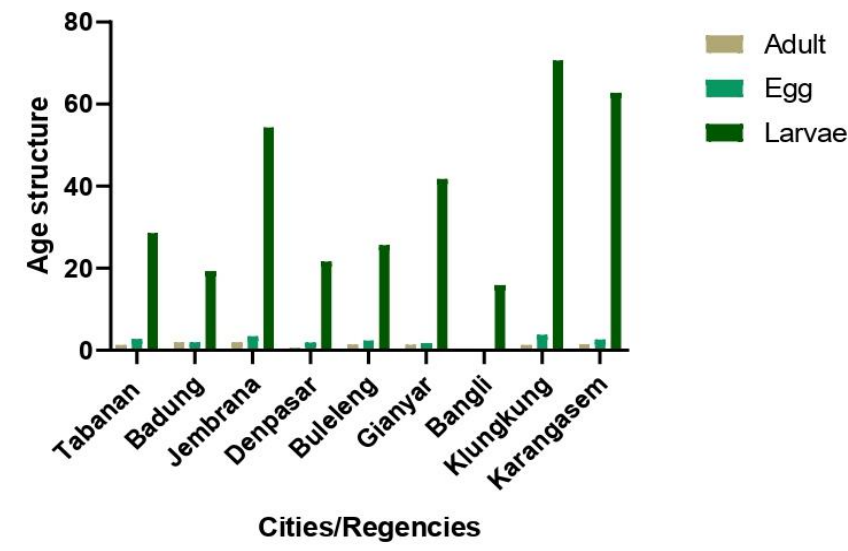

Figure 11. Age structure of $S$. frugiperda in regency/cities in Bali, Indonesia

\section{Age structure of $S$. frugiperda}

The age structure of FAW in maize cropping in each district/city in Bali varies greatly. The population of FAW larvae is more dominant compared to adult populations and egg groups. Such events are strongly related to the oviposition of adult preference to the lifespan of the host plant available in each location. Adult tend to choose younger corn crops for laying their eggs and move from one location to another (Bessin 2019; Sisay et al. 2019). In addition, the presence of FAW adults is also very difficult to monitor during the day because it is nocturnal, which is active at night, and hide during the day (Kandel and Poudel 2020).

The highest adult population was found in Badung and Jembrana districts with an average number of adult 1.94 larvae per $25 \mathrm{~m}^{2}$ while the group of eggs and larvae found was the highest in Klungkung Regency at 3.79 and 70.65 larvae per $25 \mathrm{~m}^{2}$ (Figure 11). The high population of eggs and larvae in the Klungkung Regency, caused by the host plant factor is the availability of corn crops overlapping throughout the growing season. According to Price (1991) herbivorous insects that obtain a source of feed on monoculture crops continuously and concentrated in large quantities can support the life of such insects to reproduce and survive. Adult FAW tends to spread quickly looking for young host plants to lay eggs. Therefore, the development of the FAW population will be higher in low altitude areas that grow large amounts of maize cultivated in monocultures.

\section{Attack percentage of $S$. frugiperda}

The highest percentage of attacks found in areas below 250 meters above sea level is $47.84 \%$ per plot of $25 \mathrm{~m}^{2}$, and the lowest in the altitude area above 500 meters above $0 \%$ due to the limitations of maize crops planted in the area (Figure 12). The availability of host plants becomes one of the determining factors of pest attack somewhere. The high number of populations or abundance of insect populations in a habitat is supported by the availability of feed resources both types, quantities, and quality for insect pests concerned (Capinera 2017). Shi et al. (2012) state that in

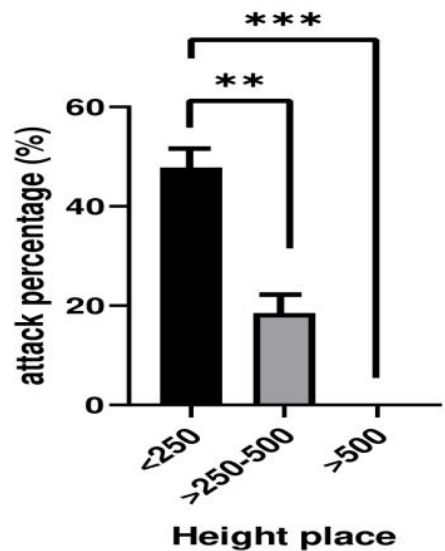

Figure 12. Attack percentage of $S$. frugiperda at the different heights of the study area in Bali, Indonesia. ** and *** : significantly different.

addition to food availability factors, the height and temperature factors also play an important role and become a limiting factor for the growth and development of insect pests. Because such factors can affect the physiology of the body, abundance, and distribution of such insects. According to Du-Plessis et al. (2020), temperature factors can adversely affect insects' fecundity, resulting in population decline. This event is reinforced by the results of Hoiss et al. (2012) research that there is a decrease in the number of insect species population with increasing height of the place. The incident was caused by a slowing down of the insect reproduction process, which affected the number of generations per unit of time (Zhang et al. 2013).

In conclusion, the characteristics of $S$. frugiperda damage to maize in Bali are indicated by the presence of instar-1 larvae grinding on young leaves leaving a transparent epidermal layer, while 2-3 instar larvae leave holes in plant leaves and 4-6 instar larvae grinding leaving the bones of the maize leaves and stems. On the top surface of the leaves, there is dirt that resembles brown sawdust. Invasion of FAW pests, $S$. frugiperda reportedly entered and attacked maize crops in Bali since January 2020. At the beginning of the entry is only found in some lowland locations, especially in Tabanan and Jembrana regency, but within 4 months and the next has spread evenly throughout the districts and cities in the Bali. Adult population and egg group from FAW, S. frugiperda were found to peak by the time the maize crop was 2 weeks after planting (WAP) while the larval population reached its peak by the time the plant was 4 WAP The highest percentage of FAW attacks was in areas below 250 meters above sea level with an average attack per observation plot of $47.84 \%$ and differ significantly when compared to other altitude-based locations in our study (Figure 12).

Control by utilizing natural enemies and bioinsecticides is still needed to control the spread of massive FAW pests that attack corn commodities in the field. This aims to assist maize farmers in increasing productivity and reducing synthetic insecticides that can damage the environmental quality and human health. 


\section{ACKNOWLEDGEMENTS}

The authors would like to thanks the Head Integrated Pest Management Laboratory (IPMLaB), Faculty of Agriculture, Udayana University, Bali, Indonesia which has provided facilities and funding assistance. The author also would like to thank I Wayan Eka Karya Utama and Wayan Agus Andi Sulhan who has assisted in observation and data tabulation. The authors are also grateful to those who have provided funding assistance from the Superior Research Study Program (Penelitian Unggulan Program Studi) of 2020 with Contract Number: B/261/UN14.2.6. II/PT.01.03/2020.

\section{REFERENCE}

Anandhi S, Saminathan VR, Yasodha P, Roseleen SSJ, Sharavanan PT, Rajanbabu V. 2020. Correlation of Fall armyworm Spodoptera frugiperda (J.E. Smith) with weather parameters in maize ecosystem. Int J Curr Microbiol Appl Sci 9(8): 1213-1218. DOI: 10.20546/ijcmas.2020.908.135

Anon. 2019. Introduction of Fall Armyworm (Spodoptera frigiperda J. E. Smith) New Pests on Maize Plants in Indonesia. [Indonesian]

Anon. 2019a. Harvested Area, Productivity, Production of Corn throughout the Province: http://www.bps.go.id/ tnmn_pgn.php [accessed 28 December 2019. [Indonesian]

Anon. 2019b. Indonesia Prepares for Battle with Fall Armyworm. Available: events/en/c/1202177/ [accessed 6 April 2021]

Anon. 2021. Pest Management on Maize. https://iimr.icar.gov.in/pestmanagement-2/. [accessed 6 April 2021].

Ba TX, Zhang YH, Zhang Z, Guan DD, Li CC, Ji ZY, Yin XT, Zhang AH, Tang QB, Liu YH, Li XR, ZhouX. 2020. The host preference and population life tables of Spodoptera frugiperda (Lepidoptera: Noctuidae) fed on maize and wheat. Plant Prot 46: 17-23.

Badenes-Perez FR, Gershenzon J, Heckel DG. 2014. Insect attraction versus plant defense: Young leaves high in glucosinolates stimulate oviposition by a specialist herbivore despite poor larval survival due to high saponin content. PLoS ONE 9(4): e95766. DOI:10.1371/journal.pone.0095766.

Barros EM, Torres JB, Ruberson JR, Oliveira MD. 2010. Development of Spodoptera frugiperda on different hosts and damage to reproductive structures in cotton. Entomol Exp Appl 137:237-245; DOI: $10.1111 / \mathrm{j} .1570-7458.2010 .01058 . x$.

Bessin R 2019. Fall Armyworm in Corn. College of Agriculture,Food and Environment. https://entomology.ca.uky.edu/ef110.

Bhusal K, Bhattarai K. 2019. A review on Fall armyworm (Spodoptera frugiperda) and its possible management options in Nepal. J Entomol Zool Stud 7(4): 1289-1292.

CABI, FAO. 2019. Community-Based Fall Armyworm (Spodoptera frugiperda) Monitoring, Early Warning and Management, Training of Trainers Manual. First Edit. The Food and Agriculture Organization of the United Nations and CAB International

CABI. 2017. Invasive Species Compendium. CAB Int. Available: https://www.cabi.org/isc/datasheet/29810.

Capinera JL. 2017. Fall Armyworm, Spodoptera frugiperda (J.E. Smith) (Insecta: Lepidoptera: Noctuidae). http://entomology.ifas.ufl.edu/ creatures.

Chimweta M, Nyakudya IW, Jimu L, Bray Mashingaidze A. 2020. Fall armyworm Spodoptera frugiperda (J.E. Smith) damage in maize: Management options for flood-recession cropping smallholder farmers. Int J Pest Manag 66:142-154. DOI:10.1080/09670874.2019.1577514.

Davis F, Williams W. 1992. Visual Rating Scales for Screening WhorlStage Corn for Resistance to Fall Armyworm. (No. Technical Bulletin 186). Mississippi State University, MS39762, USA.

Deole S, Paul N. 2018. First report of fall armyworm, Spodoptera frugiperda (J.E. Smith), their nature of damage and biology on maize crop at Raipur, Chhattisgarh. J Entomol Zool Stud 6(6): 219-221.
Dhar T, Bhattacharya S, Chatterjee H, Senapati SK, Bhattacharya PM, Poddar P et al. 2019. Occurrence of Fall armyworm Spodoptera frugiperda (J. E. Smith) (Lepidoptera: Noctuidae) on maize in West Bengal, India and its field life table studies. J Entomol Zool Stud 7: 869-875.

Du-Plessis H, Schlemmer M-L, Van den Berg J. 2020. The effect of temperature on the development of Spodoptera frugiperda (Lepidoptera: Noctuidae). Insects 11(4): 228. DOI: 10.3390/insects 11040228 .

Edmeades GO, Trevisan W, Prasanna BM, Campos H. 2017. Tropical maize (Zea mays L.). In: Genetic Improvement of Tropical Crops. Springer International Publishing. DOI: 10.1007/978-3-319-5981923

Fan J, Wu P, Tian T, Ren Q, Haseeb M, Zhang R. 2020. Potential distribution and niche differentiation of Spodoptera frugiperda in Africa. Insects 11:383. DOI:10.3390/insects11060383.

Ganiger PC, Yeshwanth HM, Muralimohan K, Vinay N, Kumar ARV, Chandrashekara K. 2018. Occurrence of the new invasive pest, Fall armyworm, Spodoptera frugiperda (J.E. Smith) (Lepidoptera: Noctuidae), in the Maize Fields of Karnataka, India. Curr Sci 115: 621. DOI:10.18520/cs/v115/i4/621-623.

Goergen G, Kumar PL, Sankung SB, Togola A, Tamò M. 2016. First report of outbreaks of the Fall armyworm Spodoptera frugiperda (J E Smith) (Lepidoptera, Noctuidae), a new alien invasive pest in West and Central Africa. PLoS ONE 11: e0165632. DOI:10.1371/journal.pone.0165632.

Hoiss B, Krauss J, Potts SG, Roberts S, Steffan-Dewenter I. 2012. Altitude acts as an environmental filter on phylogenetic composition, traits and diversity in bee communities. Proc R Soc B Biol Sci 279:4447-4456. DOI:10.1098/rspb.2012.1581.

Horvat D, Šimic G, Drezner G, Lalic A, Ledencan T, Tucak M, Plavšic H, Andric L, Zdunic Z. 2020. Phenolic acid profiles and antioxidant activity of major cereal crops. Antioxidants 9(527): 1-12. DOI:10.3390/antiox9060527.

Jim F, Lou C, Philip J. 1998. Practical Statistics for Field Biology, 2nd Edition. Wiley.

Kandel S, Poudel R. 2020. Fall armyworm (Spodoptera frugiperda) in Maize: An emerging threat in Nepal and its management. Int J Appl Sci Biotechnol 8(3): 305-309. DOI: 10.3126/ijasbt.v8i3.31610.

Kansiime MK, Mugambi I, Rwomushana I, Nunda W, Lamontagne-Godwin J, Rware H, Day R. 2019. Farmer perception of fall armyworm (Spodoptera frugiperda JE Smith) and farm-level management practices in Zambia. Pest Manag Sci 75(10): 2840-2850. DOI: $10.1002 /$ ps.5504.

Montezano DG, Specht A, Sosa-Gomez DR, Roque-Specht VF, SousaSilva JC, Paula-Moraes, Peterson JA, Hunt TE. 2018. Host plants of Spodoptera frugiperda (Lepidoptera: Noctuidae) in the Americas. Afr Entomol 26(2): 286-300. DOI: 10.4001/003.026.0286.

Nelly N, Hamid H, Lina EC, Yunisman. 2021. The use of several maize varieties by farmers and the infestation of Spodoptera frugiperda (Noctuidae: Lepidoptera). IOP Conf Ser Earth Environ Sci 662: 012020. DOI: $10.1088 / 1755-1315 / 662 / 1 / 012020$.

Pathania M, Verma A, Singh M, Arora PK, Kaur N. 2020. Influence of abiotic factors on the infestation dynamics of whitefly, Bemisia tabaci (Gennadius 1889) in cotton and its management strategies in NorthWestern India. Int J Trop Insect Sci 40: 969-981. DOI: $10.1007 / \mathrm{s} 42690-020-00155-2$.

Prasanna B, Huesing JE, Eddy R, Peschke VM. 2018. Fall armyworm in Africa: A guide for integrated pest management. Mex CDMX CIMMYT First Edit: 45-62.

Price PW. 1991. The plant vigor hypothesis and herbivore attack. Oikos 62: 244. DOI: $10.2307 / 3545270$.

Putrasamedja S, Setiawati W, Lukman L, Hasyim A. 2016. The appearance of several onion clones and their relationship with the intensity of attack by plant pests. J. Hort. 22:349. DOI:10.21082/jhort.v22n4.2012.p349-359. [Indonesian]

Ratnadass A, Fernandes P, Avelino J, Habib R. 2012. Plant species diversity for sustainable management of crop pests and diseases in agroecosystems: A review. Agron Sustain Dev 32: 273-303. DOI:10.1007/s13593-011-0022-4

Reddy J. 2019. Fall Armyworm Control Methods and Symptoms. Agrifarming. Retrieved from https://www.agrifarming.in/fallarmyworm-control-methods-and-symptoms. [accessed 7 April 2021].

Rwomushana I, Bateman M, Beale T, Beseh P, Cameron K, Chiluba M, et al. 2018. Fall armyworm: Impacts and implications for Africa. Outlooks Pest Manag 28: 18-19. DOI:10.1564/v28_oct_02. 
Santiago R, Malvar RA, Baamonde MD, Revilla P, Souto XC. 2005. Free phenols in maize pith and their relationship with resistance to Sesamia nonagrioides (Lepidoptera: Noctuidae) attack. J Econ Entomol 98:1349-1356. DOI:10.1603/0022-0493-98.4.1349.

Shah TR, Prasad K, Kumar P. 2016. Maize-A potential source of human nutrition and health: A review. Cogent Food Agric 2: 1166995. DOI:10.1080/23311932.2016.1166995.

Shi P, Zhong L, Sandhu HS, Ge F, Xu X, Chen W. 2012. Population decrease of Scirpophaga incertulas Walker (Lepidoptera Pyralidae) under climate warming. Ecol Evol 2: 58-64. DOI:10.1002/ece3.69.

Sisay B, Tefera T, Wakgari M, Ayalew G, Mendesil E .2019. The efficacy of selected synthetic insecticides and botanicals against Fal armyworm, Spodoptera frugiperda, in maize. Insects 10(2): 45. DOI 10.3390/insects10020045.

Sparks AN. 1979. A review of the biology of the Fall armyworm. Fla Entomol 62:82. DOI: 10.2307/3494083.

Suby SB, Soujanya1 PL, Yadava P, Patil J, Subaharan K, Prasad GS, Babu KS, Jat SL, Yathish KR, Vadassery J, Kalia VK, Bakthavatsalam N, Shekhar JC, Rakshit S. 2020. Invasion of fall armyworm (Spodoptera frugiperda) in India: Nature, distribution, management and potential impact. Curr Sci 119(1): 44-51.

Supartha IW, Sunari AAAAS, Putra IGPBK, Yudha IKW, Wiradana PA 2021. Invasion, population development and attack intensity of the
Fall armyworm Spodoptera frugiperda J.E. Smith (Lepidoptera: Noctuidae) on two variety corn in Serongga Village, Gianyar regency, Bali-Indonesia. Technol Rep Kansai Univ 10: 645-654.

Supartha IW, Yudha IKW, Wiradana PA, Susila IW. 2020. Response of parasitoids to invasive pest Phenacoccus manihoti Matile-Ferrero (Hemiptera: Pseudococcidae) on cassava crop in Bali, Indonesia. Biodiversitas 21(10): 4543-4549. DOI: 10.13057/biodiv/d211011.

Tendeng E, Labou B, Diatte M, Djiba S, Diarra K. 2019. The Fall armyworm Spodoptera frugiperda (J.E. Smith), a new pest of maize in Africa: Biology and first native natural enemies detected. Int J Biol Chem Sci 13(2): 1011-1026. DOI: 10.4314/ijbcs.v13i2.35.

Wu ZW, Shi PQ, Zeng YH, Huang WF, Huang QZ, Ma X H, Guo LZ. 2019. Population life tables of Spodoptera frugiperda (Lepidoptera: Noctuidae) fed on three host plants. Plant Prot 45: 59-64

Yasa IWS, Supartha IW, Susila IW. 2020 Population abundance and parasitization level of indigenous parasitoids to the invasive pest, Liriomyza trifolii (Burgess)(Diptera: Agromyzidae) in Bali. Agrotrop J Agric Sci 10:59. DOI:10.24843/AJoAS.2020.v10.i01.p07. [Indonesian]

Zhang W, Zhao F, Hoffmann AA, Ma C-S. 2013. A single hot event that does not affect survival but decreases reproduction in the Diamondback moth, Plutella xylostella. PLoS ONE 8: e75923. DOI:10.1371/journal.pone.0075923. 